Article

\title{
Analgesic Effect of 5-(3,4-Dihydroxyphenyl)-3-hydroxy-1-(2- hydroxyphenyl)penta-2,4-dien-1-one in Experimental Animal Models of Nociception
}

\author{
Nadhirah Kamarudin ${ }^{1}$ (D), Nadia Hisamuddin ${ }^{1}$, Hui Ming Ong ${ }^{2}$, Ahmad Farhan Ahmad Azmi ${ }^{2}$, \\ Sze Wei Leong ${ }^{3,4}$, Faridah Abas ${ }^{4,5}$ (i), Mohd Roslan Sulaiman ${ }^{2}$ and \\ Wan Mastura Shaik Mossadeq ${ }^{1, * \text { (i) }}$ \\ 1 Department of Veterinary Preclinical Sciences, Faculty of Veterinary Medicine, Universiti Putra Malaysia, \\ Serdang 43400, Selangor, Malaysia; nurnadhirahkamarudin@gmail.com (N.K.); \\ nadiahisamuddinn@gmail.com (N.H.) \\ 2 Department of Biomedical Sciences, Faculty of Medicine and Health Sciences, Universiti Putra Malaysia, \\ Serdang 43400, Selangor, Malaysia; oguiming85@gmail.com (H.M.O.); \\ farhanazmirahman@gmail.com (A.F.A.A.); mrs@upm.edu.my (M.R.S.) \\ 3 Department of Microbiology, Faculty of Biotechnology and Biomolecular Sciences, \\ Universiti Putra Malaysia, Serdang 43400, Selangor, Malaysia; leongszewei@upm.edu.my \\ 4 Laboratory of Natural Products, Institute of Bioscience, Universiti Putra Malaysia, Serdang 43400, Selangor, \\ Malaysia; faridah_abas@upm.edu.my \\ 5 Department of Food Science, Faculty of Food Science and Technology, Universiti Putra Malaysia, \\ Serdang 43400, Selangor, Malaysia \\ * Correspondence: wmastura@upm.edu.my; Tel.: +60-3-8609-3407
}

Academic Editors: Marcello Locatelli and Simone Carradori

Received: 8 June 2018; Accepted: 6 July 2018; Published: 21 August 2018

\begin{abstract}
Curcuminoids derived from turmeric rhizome have been reported to exhibit antinociceptive, antioxidant and anti-inflammatory activities. We evaluated the peripheral and central antinociceptive activities of 5-(3,4-dihydroxyphenyl)-3-hydroxy-1-(2-hydroxyphenyl)penta-2,4-dien-1-one (DHHPD), a novel synthetic curcuminoid analogue at $0.1,0.3,1$ and $3 \mathrm{mg} / \mathrm{kg}$ (intraperitoneal), through chemical and thermal models of nociception. The effects of DHHPD on the vanilloid and glutamatergic systems were evaluated through the capsaicin- and glutamate-induced paw licking tests. Results showed that DHHPD significantly $(p<0.05)$ attenuated the writhing response produced by the $0.8 \%$ acetic acid injection. In addition, 1 and $3 \mathrm{mg} / \mathrm{kg}$ of DHHPD significantly $(p<0.05)$ reduced the licking time spent by each mouse in both phases of the $2.5 \%$ formalin test and increased the response latency of mice on the hot-plate. However, the effect produced in the latter was not reversed by naloxone, a non-selective opioid receptor antagonist. Despite this, DHHPD decreased the licking latency of mice in the capsaicin- and glutamate-induced paw licking tests in a dose response manner. In conclusion, DHHPD showed excellent peripheral and central antinociceptive activities possibly by attenuation of the synthesis and/or release of pro-inflammatory mediators in addition to modulation of the vanilloid and glutamatergic systems without an apparent effect on the opioidergic system.
\end{abstract}

Keywords: pain; 5-(3,4-dihydroxyphenyl)-3-hydroxy-1-(2-hydroxyphenyl)penta-2,4-dien-1-one; turmeric; antinociceptive; vanilloid; glutamatergic; opioid 


\section{Introduction}

Pain decreases the quality of a person's life and results in expensive medical expenses and economic losses to the society [1]. The bodily and emotional experience related to this condition is often associated with potential or actual tissue damage as a consequence of exposure to intense or damaging stimuli [2].

Pain management primarily rely on anti-inflammatory and antinociceptive medications such as opiates and non-steroidal anti-inflammatory drugs (NSAIDs). Drugs that are prescribed for the management or control of pain associated with inflammatory conditions are usually antagonists of endogenous pro-inflammatory mediators such as prostaglandins, leukotrienes and histamine. These drugs target the $\mathrm{H} 1$ receptor for histamine, cyclooxygenases 1 and 2, tumour necrosis factor- $\alpha$ and cycteinyl leukotrienes C4 and D4 receptors, to name a few [3]. Numerous animal studies dated as far back as in the 1970s and 1980s indicated that the opening of specific $\mathrm{K}^{+}$channels by agonists of many G-protein coupled receptors (e.g., serotonin 5-HT1A, adenosine A1, $\alpha 2$-adrenoreceptors, muscarinic M2, GABA, opioid and cannabinoid receptors), tricyclic antidepressants, NSAIDs and natural products, have all induced antinociceptive activity in the acute and chronic models of pain [4]. It then led scientists to hypothesize that blockade of these channels by pro-inflammatory mediators and specific channel blockers may produce increased hyperalgesia during inflammation. However, the prolonged use of these drugs is often accompanied with side effects such as gastrointestinal ulcer [5], respiratory depression [1], high risk of stroke [6] and haemorrhage [7].

Narcotic agents such as morphine and codeine or synthetic derivatives possessing morphine-like properties such as heroin are potent analgesics and are frequently used for relief of severe pain in spite of their potential for abuse [8]. This group of drugs inhibit nociception by binding to the opioid receptors on the primary afferent as well as neurons in the dorsal horn of the spinal cord and in the brain, consequently exacerbating the descending inhibitory effect of nociceptive signalling at this level $[9,10]$. However, these drugs induce central and peripheral adverse side effects including drowsiness, sedation, cough suppression, vomiting, pupillary constriction, hypotension, withdrawal symptoms, pruritus and delirium [11-14]. Addicts and patients undergoing opiate-based treatments often succumb to constipation, resulting from opiate-induced cholinergic activity stimulation in the gut wall ganglia, in addition to bronchospasm, flushing and arteriolar dilatation, as a result of histamine release. Often given to patients who are undergoing treatment for chronic or long term debilitating diseases, prescriptions of narcotics in the treatment of pain have been generating a lot of controversies since use of narcotics were usually associated with tolerance and addiction in susceptible patients [15]. However, addiction to opioids, if present, is to an extent, dependent on the individual's exposure to drugs, genetic, social and psychological factors [16-19].

Hence, the search for an alternative to these medications such as naturally-occurring products is gaining attention among researchers and public in hope that these natural substances may induce desired outcomes similar to existing medication but with lesser or zero side effects.

Rhizomes have been a popular choice of remedy for various common ailments in folklore medicine due to its abundance, all year availability, low cost and effectiveness. Aside from its medicinal use, several species of rhizomes such as ginger, fingerroot, and turmeric are often used as spice in soups and dishes in the Southeast Asia region.

Zingiber zerumbet (pinecone) for example, are traditionally used by the Indians, Malays, Chinese and Hawaiians to treat inflammation, fever, wound and bruises [20]. In addition, extracts of Curcuma longa (turmeric, C. longa) have been demonstrated to be effective against cancer, cough, diabetic wounds, dermatitis, rheumatism, sinusitis, high cholesterol and AIDS [21-25]. Commonly known as 'kunyit' in Malaysia, this plant is native to tropical countries such as Malaysia, India and China.

Curcuminoids, the bioactive components of $C$. longa, exhibit antioxidant, anti-inflammatory and antinociceptive activities [26]. Despite the benefits, curcuminoids have poor bioavailability and pharmacokinetic properties [27] thus reducing their potential as alternative medicinal and therapeutic 
agents. Hence, synthesis of curcuminoid analogues with good bioavailability, solubility and biological properties is warranted.

The 5-(3,4-dihydroxyphenyl)-3-hydroxy-1-(2-hydroxyphenyl)penta-2,4-dien-1-one, or DHHPD (Figure 1) is a derivative of diarylpentanoids, an analogue of curcumin. Diarylpentanoids showed better bioavailability and greater pharmacological activities compared to curcumin as it showed significant anti-inflammatory properties in vitro [28,29]. Hence, the present study aims to evaluate the central and peripheral antinociceptive activities of DHHPD through chemical and thermal experimental animal models of nociception.<smiles>O=C(/C=C(O)/C=C/c1ccc(O)c(O)c1)c1ccccc1O</smiles>

Figure 1. Chemical structure of 5-(3,4-dihydroxyphenyl)-3-hydroxy-1-(2-hydroxyphenyl)penta-2,4-dien-1-one (DHHPD).

\section{Results}

\subsection{Acute Toxicity Study}

During the 7-day observation period, there were no abnormal behaviours, morbidity or mortality recorded. In addition, no abnormal changes were observed on the vital organs of mice during post-mortem.

\subsection{Antinociceptive Studies}

\subsubsection{Acetic Acid-Induced Writhing Test}

Figure 2 illustrates the effect of DHHPD against $0.8 \%$ acetic acid-induced abdominal constriction/writhing test. The calculated mean $\mathrm{ED}_{50}$ of DHHPD for this test was $0.28 \mathrm{mg} / \mathrm{kg}$, i.p. (CI, 0.17-0.48 mg/ $\mathrm{kg}$ ). DHHPD at the doses of 0.1, 0.3, 1 and $3 \mathrm{mg} / \mathrm{kg}$ exhibited significant $(p<0.05)$ reduction in writhing frequency by $45.9 \%, 74.9 \%, 90.7 \%$ and $97.3 \%$, respectively. Similarly, the aspirin group (ASA) inhibited writhing by $64.9 \%$ as compared to the vehicle group.

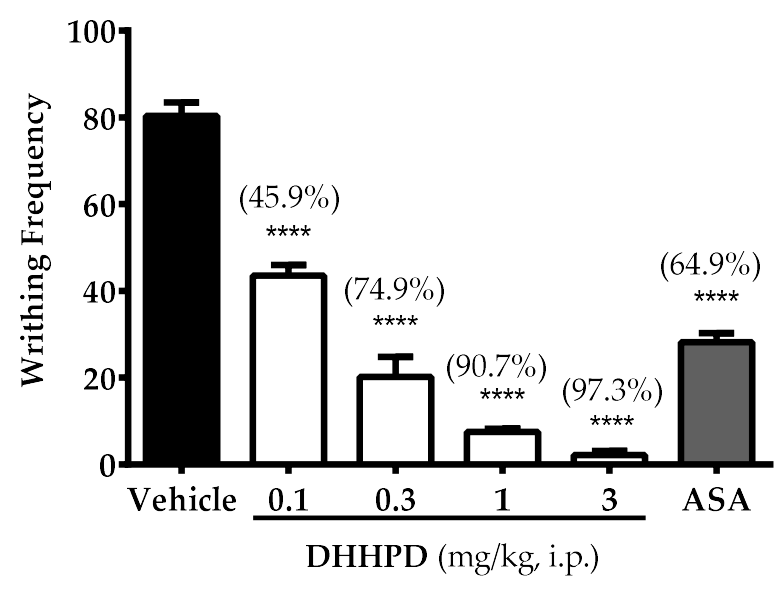

Figure 2. Effect of DHHPD against $0.8 \%$ acetic acid-induced abdominal constriction test in mice. Each column denotes the mean $\pm \operatorname{SEM}(n=6)$. The asterisks $\left(^{*}\right)$ represent significance level as compared to the vehicle group, ${ }^{* * * *} p<0.0001$ by one-way ANOVA followed by Dunnett's post hoc test. Mice were administered with vehicle $(10 \mathrm{~mL} / \mathrm{kg}$, i.p.), acetylsalicylic acid (ASA, $100 \mathrm{mg} / \mathrm{kg}$, i.p.) and DHHPD $(0.1,0.3,1$ and $3 \mathrm{mg} / \mathrm{kg}$, i.p.). 


\subsubsection{Formalin-Induced Paw Licking Test}

DHHPD at the doses of $0.1,0.3,1$ and $3 \mathrm{mg} / \mathrm{kg}$ showed significant reduction in the latency/time that each mouse spent on biting and licking the injected hind paw (sec) during the neurogenic phase by $20.9 \%, 24.1 \%, 33.8 \%$ and $43.3 \%$, respectively (Figure $3 \mathrm{a}$ ). As expected, morphine produced the highest reduction of the licking time $(76.2 \%)$ while ASA produced only a $0.9 \%$ decrease compared to vehicle.

In the late phase (Figure $3 b)$, mice treated with DHHPD (3 mg/ $\mathrm{kg}$, i.p.) recorded significant reduction in licking time by $54.3 \%$ compared to mice treated with DHHPD at doses of $0.1,0.3$ and $1 \mathrm{mg} / \mathrm{kg}$, with $5.1 \%, 9.2 \%$, and $33.4 \%$ reduction, respectively. Likewise, the ASA and morphine groups showed $66.5 \%$ and $99.9 \%$ inhibition, respectively. The calculated mean $\mathrm{ED}_{50}$ of DHHPD for the early and late phases were $0.82 \mathrm{mg} / \mathrm{kg}$, i.p. (CI, $0.54-1.3 \mathrm{mg} / \mathrm{kg}$ ) and $0.87 \mathrm{mg} / \mathrm{kg}$, i.p. (CI, $0.69-1.1 \mathrm{mg} / \mathrm{kg}$ ), respectively. However, DHHPD at all doses reduced the latency of licking compared to the vehicle group. Compared to other doses, DHHPD at 1 and $3 \mathrm{mg} / \mathrm{kg}$ significantly $(p<0.05)$ reduced the nocifensive behaviour in both phases of the test.

(a)

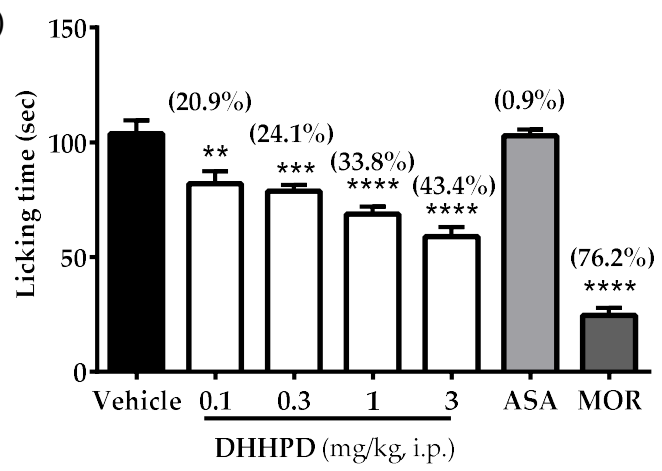

(b)

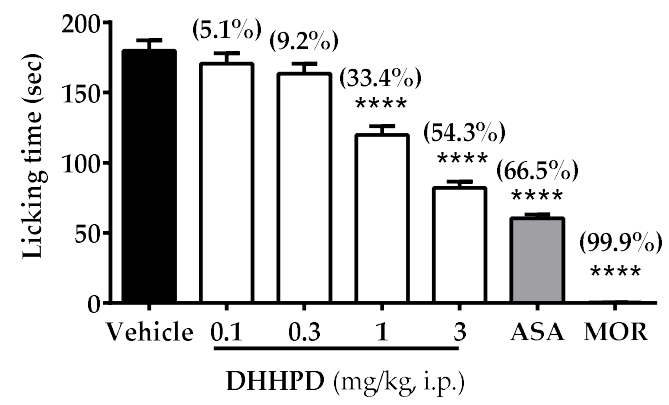

Figure 3. Effect of DHHPD against $2.5 \%$ formalin-induced paw licking test in mice. (a) Early/neurogenic phase; (b) Late/inflammatory phase. Each column represents the mean $\pm \operatorname{SEM}(n=6)$. The asterisks $\left(^{*}\right)$ denote the significance level as compared to the vehicle group, ${ }^{* *} p<0.01,{ }^{* * *} p<0.001,{ }^{* * * *} p<0.0001$ by one-way ANOVA followed by Dunnett's post hoc test. Mice were administered with vehicle $(10 \mathrm{~mL} / \mathrm{kg}$, i.p.), acetylsalicylic acid (ASA, $100 \mathrm{mg} / \mathrm{kg}$, i.p.) and DHHPD (0.1, 0.3, 1 and $3 \mathrm{mg} / \mathrm{kg}$, i.p.).

\subsubsection{Hot-Plate Test}

Intraperitoneal administration of DHHPD prolonged the response latency in mice at different time intervals, as shown in Table 1. A significant $(p<0.05)$ increase in response latency was observed beginning at $60 \mathrm{~min}$ and continued until $90 \mathrm{~min}$, for all doses of DHHPD. The response latency for mice which received 0.1 and $0.3 \mathrm{mg} / \mathrm{kg}$ DHHPD gradually tapered off from this point until the end of the experiment. However, a continuous increase in latency was observed in mice which received DHHPD at 1 and $3 \mathrm{mg} / \mathrm{kg}$ until $150 \mathrm{~min}$. Regardless, mice which received morphine $(5 \mathrm{mg} / \mathrm{kg}$, s.c.) showed the highest response latency compared to other treatment groups at all intervals until the end of the experiment. In addition, naloxone significantly antagonised analgesia produced by morphine at all intervals of the experiment.

\subsubsection{Involvement of the Opioidergic System}

Naloxone ( $5 \mathrm{mg} / \mathrm{kg}$, i.p.) did not antagonize the antinociceptive activity produced by the highest dose of DHHPD (3 mg/kg, i.p.) at all intervals as shown in Table 1. 
Table 1. Effect of DHHPD against the hot-plate test in mice.

\begin{tabular}{|c|c|c|c|c|c|c|c|c|c|c|}
\hline \multirow[b]{2}{*}{ Treatment } & & \multicolumn{9}{|c|}{ Interval Following Treatment (min) } \\
\hline & & 0 & 30 & 60 & 90 & 120 & 150 & 180 & 210 & 240 \\
\hline & Dose (mg/kg) & & & & & Latency Time (s) & & & & \\
\hline Vehicle $(10 \mathrm{~mL} / \mathrm{kg})$ & - & $6.16 \pm 0.17$ & $6.83 \pm 0.30$ & $6.67 \pm 0.33$ & $6.67 \pm 0.21$ & $6.83 \pm 0.31$ & $6.67 \pm 0.21$ & $6.83 \pm 0.31$ & $6.33 \pm 0.21$ & $6.30 \pm 0.03$ \\
\hline \multirow[t]{4}{*}{ DHHPD } & 0.1 & $7.08 \pm 0.35$ & $7.94 \pm 1.11$ & $8.11 \pm 0.56$ & $9.58 \pm 1.31 * *$ & $8.79 \pm 0.45$ & $7.29 \pm 0.54$ & $7.08 \pm 0.36$ & $6.57 \pm 0.59$ & $8.17 \pm 0.84$ \\
\hline & 0.3 & $7.34 \pm 0.34$ & $8.30 \pm 0.93$ & $9.28 \pm 0.34 *$ & $10.01 \pm 0.72 * *$ & $9.62 \pm 0.80 *$ & $8.83 \pm 0.38$ & $7.92 \pm 0.44$ & $8.21 \pm 0.48$ & $8.51 \pm 0.63$ \\
\hline & 1 & $6.52 \pm 0.23$ & $7.58 \pm 1.10$ & $11.80 \pm 1.22^{* * * *}$ & $10.14 \pm 1.34^{* * *}$ & $9.67 \pm 0.42 *$ & $10.60 \pm 0.50^{* * * *}$ & $10.80 \pm 1.14^{* * * *}$ & $7.59 \pm 0.48$ & $8.30 \pm 0.90$ \\
\hline & 3 & $7.14 \pm 0.39$ & $9.51 \pm 0.43 *$ & $10.93 \pm 0.78^{* * * *}$ & $11.55 \pm 1.06^{* * * *}$ & $12.34 \pm 1.07^{* * * *}$ & $10.23 \pm 0.45^{* * *}$ & $8.84 \pm 0.53$ & $9.41 \pm 0.61 * *$ & $7.68 \pm 0.34$ \\
\hline Morphine & 5 & $7.50 \pm 0.34$ & $18.33 \pm 0.67^{* * * *}$ & $17.00 \pm 0.82^{* * * *}$ & $16.33 \pm 0.42^{* * * *}$ & $16.33 \pm 0.99^{* * * *}$ & $15.33 \pm 0.62^{* * * *}$ & $15.17 \pm 0.40^{* * * *}$ & $14.83 \pm 0.40^{* * * *}$ & $13.70 \pm 0.05$ \\
\hline Naloxone + DHHPD & $5+3$ & $7.13 \pm 0.22$ & $08.56 \pm 0.52$ & $9.79 \pm 1.05$ & $9.01 \pm 0.89$ & $13.76 \pm 1.03$ & $9.95 \pm 0.43$ & $8.25 \pm 0.71$ & $7.30 \pm 0.53$ & $7.88 \pm 0.35$ \\
\hline Naloxone + Morphine & $5+5$ & $6.33 \pm 0.21$ & $6.67 \pm 0.33^{\#}$ & $6.67 \pm 0.33^{\#}$ & $6.50 \pm 0.22 \#$ & $7.00 \pm 0.37^{\#}$ & $6.50 \pm 0.22 \#$ & $6.83 \pm 0.17$ \# & $6.50 \pm 0.22 \#$ & $6.36 \pm 0.01$ \# \\
\hline
\end{tabular}

Results are presented as mean \pm SEM of latency time (s) of six mice. The asterisks $\left({ }^{*}\right)$ represent the significance level compared to control, $p<0.5, * p<0$.
by two-way ANOVA followed by Bonferroni's post hoc test. The hash (\#) denotes the significance level, ${ }^{*} p<0.0001$ compared to the morphine group. 


\subsubsection{Capsaicin-Induced Paw Licking Test}

Figure 4 depicts the effect of DHHPD against capsaicin-induced paw licking test in mice. There were significant $(p<0.05)$ reductions in the licking time of mice treated with DHHPD at the doses of $0.1,0.3,1$ and $3 \mathrm{mg} / \mathrm{kg}$ by $26.9 \%, 29.5 \%, 37.4 \%$ and $57.6 \%$, respectively. However, the highest reduction was produced by capsazepine (69.1\%). The calculated mean of $\mathrm{ED}_{50}$ for DHHPD in this test was $1.2 \mathrm{mg} / \mathrm{kg}$, i.p. (CI, $0.67-2.0 \mathrm{mg} / \mathrm{kg})$.

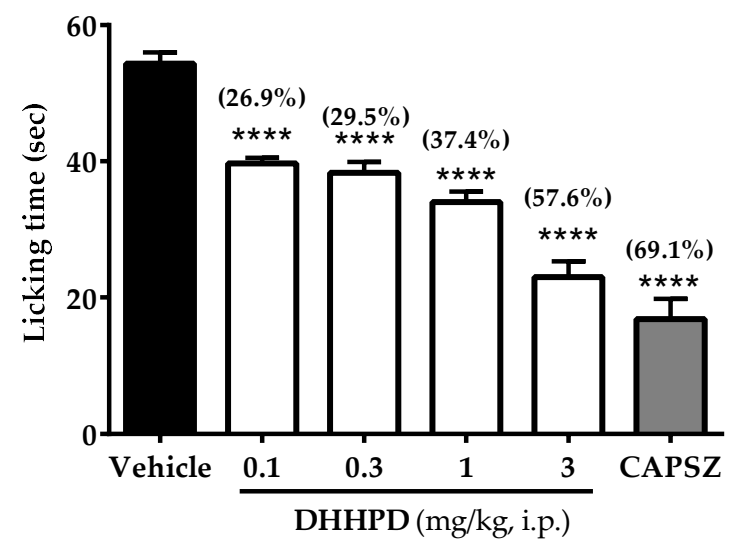

Figure 4. Effect of DHHPD against capsaicin-induced paw licking test in mice. Each column denotes the mean $\pm \operatorname{SEM}(n=6)$. The asterisks $\left({ }^{*}\right)$ represent the significance level as compared to the vehicle group, ${ }^{* * * *} p<0.0001$ by one-way ANOVA followed by Dunnett's post hoc test. Mice were administered with vehicle $(10 \mathrm{~mL} / \mathrm{kg}$, i.p.), acetylsalicylic acid (ASA, $100 \mathrm{mg} / \mathrm{kg}$, i.p.) and DHHPD $(0.1,0.3,1$ and $3 \mathrm{mg} / \mathrm{kg}$, i.p.).

\subsubsection{Glutamate-Induced Paw Licking Test}

The effect of DHHPD on the glutamate-induced paw licking test is shown in Figure 5. All doses of DHHPD $(0.1,0.3,1$ and $3 \mathrm{mg} / \mathrm{kg})$ produced significant $(p<0.05)$ reductions of licking time by $31.4 \%, 39.1 \%, 44.7 \%$ and $52.1 \%$, respectively. ASA produced an inhibition of $54.5 \%$, similar to the result produced by the highest dose of DHHPD. The calculated mean $\mathrm{ED}_{50}$ of DHHPD was $0.54 \mathrm{mg} / \mathrm{kg}$, i.p. $(\mathrm{CI}, 0.2-1.4 \mathrm{mg} / \mathrm{kg})$.

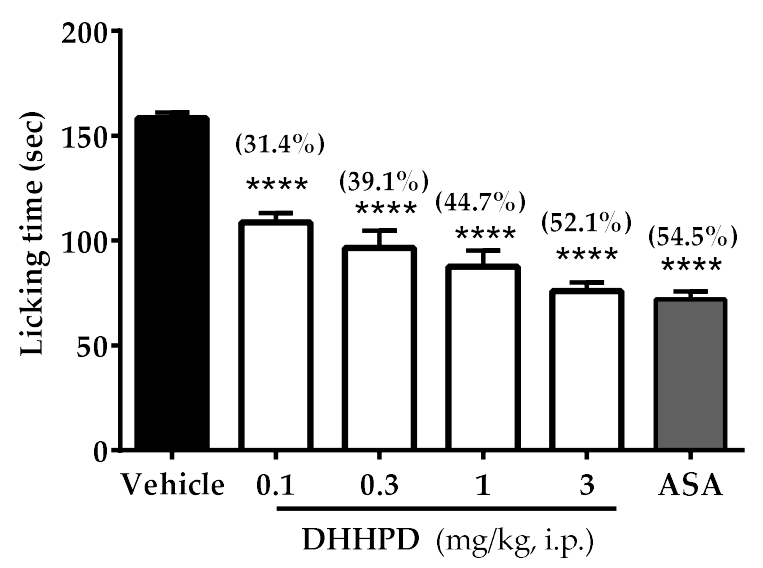

Figure 5. Effect of DHHPD against glutamate-induced paw licking test in mice. Each column represents the mean $\pm \operatorname{SEM}(n=6)$. The asterisks $\left(^{*}\right)$ denote the significance level as compared to the vehicle group, ${ }^{* * * *} p<0.0001$ by one-way ANOVA followed by Dunnett's post hoc test. Mice were pre-treated with vehicle (10 mL/kg, i.p.), acetylsalicylic acid (ASA, $100 \mathrm{mg} / \mathrm{kg}$, i.p.) and DHHPD (0.1, 0.3, 1 and $3 \mathrm{mg} / \mathrm{kg}$, i.p.). 


\subsection{Motor Performance Test}

\section{Rotarod Test}

The effect of DHHPD on rotarod test is shown in Figure 6. DHHPD at doses of 0.1, 0.3, 1 and $3 \mathrm{mg} / \mathrm{kg}$ (i.p.) did not change the motor performance of mice compared to the vehicle group. In contrast, mice which received diazepam $(4 \mathrm{mg} / \mathrm{kg}$, i.p. $)$ demonstrated significant $(p<0.05)$ alterations in the motor performance or permanence on the rotarod.

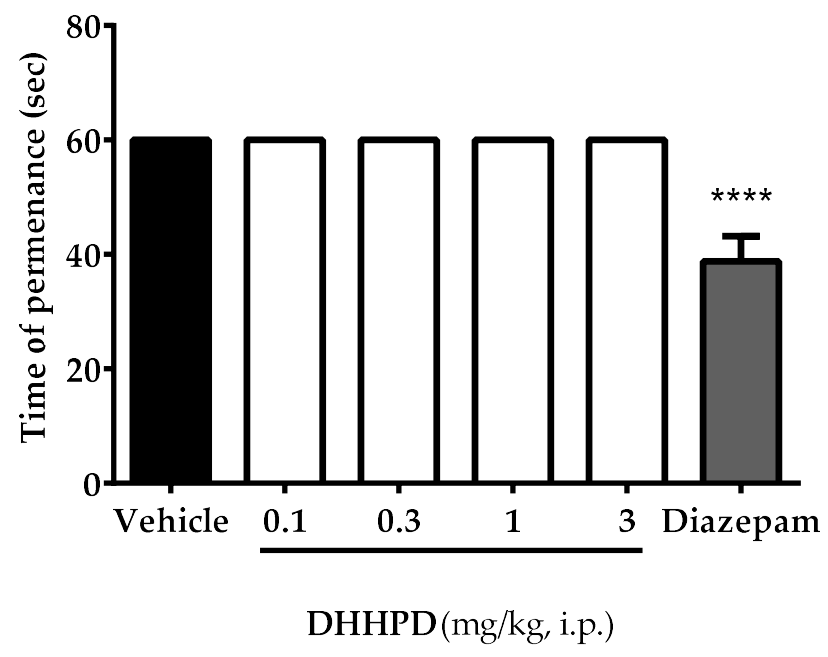

Figure 6. Effect of DHHPD on the rotarod test in mice. Each column denotes the mean \pm SEM $(n=6)$. The asterisks $\left(^{*}\right)$ represent the significance level as compared to the vehicle group, ${ }^{* * *} p<0.0001$ by one-way ANOVA followed by Dunnett's post hoc test. Mice were pre-treated with vehicle $(10 \mathrm{~mL} / \mathrm{kg}$, i.p.), diazepam (4 mg/kg, i.p.) and DHHPD (0.1, 0.3, 1 and $3 \mathrm{mg} / \mathrm{kg}$, i.p.).

\section{Discussion}

The acetic acid-induced abdominal constriction test is one of the most sensitive tests to evaluate the peripheral analgesic activities of novel drugs, compound, derivatives or synthetic substances [30,31]. However, the effects produced are usually deemed non-specific, as the writhing response could be attenuated by antihistamines, adrenergic blockers and muscle relaxants [32,33]. Despite its non-specificity, this chemical model of nociception offers an immediate result on the analgesic properties of the aforementioned substances and products at the peripheral level. For instance, an intraperitoneal administration of acetic acid sensitizes the peripheral nociceptors producing pain as a result. The signals produced as a consequence to this event are transmitted to the central nervous system which will trigger the liberation of pro-inflammatory mediators such as histamine, bradykinin, serotonin, prostaglandins, substance $\mathrm{P}$ and endogenous enzymes such as lipoxygenase (LOX) and cyclooxygenase (COX-1 and COX-2) into the peritoneal fluid [30,31]. This series of events further sensitizes the nociceptors and the cycle is repeated until the algogenic agent or irritant is removed from the system or site of injury. NSAIDs which are often used in pain management work by attenuating the synthesis and/or release of pro-inflammatory mediators such as prostaglandins or enzymes which play a key role in inflammation such as LOX and COX. Drugs, natural product compounds or derivatives that induce antinociceptive activity in the acetic acid-induced abdominal constriction test are said to resemble the NSAIDs' mechanism of action and are often considered as a promising alternative to peripherally-acting drugs [31].

Our present data showed that DHHPD at all doses significantly reduced the frequency of writhing comparably to ASA. This indicates that DHPPD may resemble NSAIDs in view of its mechanism of action in inducing analgesia. As the results of this test may be reproduced by other muscle relaxants or sedative agents, the rotarod test is required to rule out this possibility. Our data showed that mice were 
able to maintain their permanence on the rotarod, implying that the administration of DHHPD did not induce any sedative or muscle relaxing activity at all doses tested. In addition to the writhing test, highly specific tests such as the formalin-induced paw licking and hot-plate tests are recommended to verify the results obtained [34].

The $2.5 \%$ and $5 \%$ formalin-induced paw-licking tests are used to validate the peripheral and central antinociceptive effects of any novel drug, compound or substances. This test produces a distinct biphasic nociceptive response commonly referred to as the neurogenic/early phase and inflammatory /late phase [35].

An intraplantar injection of formalin on a mouse hind paw promotes direct activation of nociceptive neurons through the involvement of the C-fibres [36,37]. Consequently, neuropeptides such as substance $\mathrm{P}$ and bradykinin are released [38-40]. Pain produced during 0-5 min post formalin injection (neurogenic phase) may be mediated by the activation of transient receptor potential vanilloid 1 (TRPV1) [30]. During this phase, NSAIDs which specifically inhibit COX activity remain less effective in attenuating the nocifensive behaviour exhibited by mice compared to centrally-acting drugs such as morphine [41]. Our present results showed that ASA did not inhibit the licking time of mice in the formalin test during the early phase which confirms the previous findings. Unlike ASA, DHHPD at $0.1,0.3,1$ and $3 \mathrm{mg} / \mathrm{kg}$ reduced the latency of licking during this phase but the effects produced by DHHPD at all doses were not as effective as morphine.

The late phase or inflammatory phase involves the release of several inflammatory mediators [31] such as histamine, serotonin, bradykinin, prostaglandin and excitatory amino acids as the tissue progressively undergo damage [42]. Similar to ASA, DHHPD at 1 and $3 \mathrm{mg} / \mathrm{kg}$ significantly reduced the latency of licking in this phase indicating that it may reduce and/or inhibit the synthesis or release of these mediators or is partly involved in modulating the transduction pathways in the control of pain at the peripheral level and hence, reduces the painful sensation in mice. Moreover, DHHPD at these doses significantly reduced the licking time in not only one but both phases of the formalin test. It is suggested that centrally-acting drugs such as opiates inhibit the nocifensive behaviour produced in both phases of the test whereas peripherally-acting drugs inhibit abnormal behaviour only during the late phase [43]. Thus, DHHPD at 1 and $3 \mathrm{mg} / \mathrm{kg}$ may resemble a centrally-acting drug in inducing analgesia, although the same is untrue for lower doses of DHHPD. Thus, further assessment such as the hot-plate test that is considered as a more specific test for the screening of centrally-acting drugs is recommended for confirmation. Regardless, the reduction of licking behaviour by 1 and $3 \mathrm{mg} / \mathrm{kg}$ DHHPD observed during the late phase of the $2.5 \%$ formalin test corresponds to effect produced by the same doses in the acetic-acid writhing test, confirming an involvement of peripherally mediated analgesia.

The hot-plate test is a thermally-induced pain model that evokes a spinal reflex or behavioural reaction and is often used to assess extracts or compounds that produces supra-spinal analgesia [30,34]. The present results showed that DHHPD at 1 and $3 \mathrm{mg} / \mathrm{kg}$ significantly prolonged the response latency in mice, confirming centrally-acting activities which correspond well with the results obtained from the formalin test.

The hot-plate test can also be used to evaluate the involvement of opioid-mediated mechanism [44]. This mechanism of action involves the activation of either the mu $(\mu)$, kappa $(k)$ or delta $(\delta)$ opioid receptors [45]. Furthermore, the involvement of opioid receptor in compound- or substance-induced analgesia can be investigated through the pre-treatment of mice with naloxone, a non-selective opioid receptor antagonist [46]. A significant reversal of the antinociceptive effect produced suggests that the effects observed may involve an opioid-mediated mechanism [44]. However, our results showed that naloxone did not reverse the antinociceptive response produced by DHHPD indicating that the central analgesic activity of DHHPD was not mediated through the opioidergic system. Despite this, a prolongation of response latency by the highest doses of DHHPD in this test confirms the central activity exhibited by these doses during the early/neurogenic phase of the $2.5 \%$ formalin test. 
We determined the involvement of Transient Receptor Potential Vanilloid 1 (TRPV1) in DHHPD-induced analgesia. This ligand-gated non-selective channel can be activated by high temperature $\left(>43^{\circ} \mathrm{C}\right)$, protons, and capsaicin, a phenolic compound found in the hot chilli peppers which is responsible for its burning and irritant effect [47,48]. An intraplantar injection of capsaicin $(1.6 \mu \mathrm{g} /$ paw, $20 \mu \mathrm{L})$ for instance, induces nocifensive responses such as licking and biting of the injected paw. Capsazepine, a standard reference drug for this test, has been shown to potently block TRPV1 receptor to induce analgesia and hence, reduces duration of licking and biting of the affected paw. In the present study, the administration of DHHPD $(0.1,0.3,1$ and $3 \mathrm{mg} / \mathrm{kg}$, i.p.) inhibited the nocifensive response in the capsaicin-induced paw licking test, suggesting the inactivation of TRPV1 receptors in the induction of analgesia. Our result is in accordance to $[47,49,50]$, whereby curcumin antagonizes the TRPV1 receptors by reducing the rise in calcium induced by capsaicin administration and inward flow of current in the dorsal root ganglion neurons in both rats and mice. The detailed effects of DHHPD on calcium flow and higher centres require further investigation.

Glutamate receptors also play a crucial role in the pain pathway that modulates peripheral, spinal and supra-spinal analgesia [51]. This test evoked paw-licking and paw-biting behaviours. An intraplantar injection of glutamate solution activates the glutamatergic system via its specific ionotropic glutamate receptors (iGluRs), AMPA ( $\alpha$-amino-3-hydroxy-5-methyl-D-aspartate), NMDA ( $N$-methyl-D-aspartate), kainate (KA) and metabotropic glutamate receptors (mGluRs) [52,53]. This system may also be mediated by the release of nitric oxide (NO) or other NO-derived substances [40]. The release of NO further increases the production of pro-inflammatory mediators such as cytokines, reactive oxygen species (ROS) and prostanoids [54,55]. DHHPD has in fact, been shown to suppress NO in vivo [28]. Furthermore, administration of DHHPD $(0.1,0.3,1$ and $3 \mathrm{mg} / \mathrm{kg}$, i.p.) significantly attenuated the glutamate-induced paw-licking test, suggesting that DHHPD induces analgesia possibly by modulating the glutamatergic system through activation of the ionotropic and/or metabotropic glutamate receptors, and the suppression of NO production.

Lastly, intraperitoneal administration of DHHPD at all doses for seven consecutive days did not induce any mortality, morbidity, behavioural changes or apparent gross post-mortem lesions in the vital organs of mice. These results suggest that, in addition to the protective effects seen in all models of nociception evaluated, DHHPD did not appear to impair the function of vital organs macroscopically and at this point considered safe for use.

\section{Materials and Methods}

\subsection{Synthesis of DHHPD}

DHHPD was synthesized in the Laboratory of Natural Products, Institute of Bioscience, Universiti Putra Malaysia (UPM), Serdang, Malaysia by Dr Leong Sze Wei and associates. The synthesis process of DHHPD involved a series of reactions including Knoevenagel reaction, phenolic esterification, Baker-Venkataraman rearrangements, and demethylation [28]. Briefly, a mixture containing 3,4-dimethoxybenzaldehyde, malonic acid and piperidine in pyridine underwent a reflux process to produce a mixture that was poured unto a flask containing cold diluted hydrochloric acid $(\mathrm{HCl})$. The resulting precipitate was filtered and washed to afford mixture I. Following this process, phosphoryl chloride $\left(\mathrm{POCl}_{3}\right)$ was added to mixture I and 2-hydroxyacetophenone in pyridine. The reaction mixture was then poured into cold diluted $\mathrm{HCl}$, followed by extraction with ethyl acetate (EA). The organic layer was dried over the anhydrous magnesium sulphate and concentrated in vacuo before purification by open column chromatography to produce mixture II.

Next, ground potassium hydroxide pellets were added to a flask containing mixture II in pyridine. This mixture was poured into cold diluted $\mathrm{HCl}$ and then dried over anhydrous magnesium sulphate and evaporated under vacuo. Then, the solvent was purified with open column chromatography creating mixture III. 
Boron tribromide $\left(\mathrm{BBr}_{3}\right)$ was added to mixture III in dry dichloromethane at freezing point. Then, mixture III was extracted with EA and dried over anhydrous magnesium sulphate to produce an organic layer which was dried in vacuo using a rotary evaporator (Rotavapor ${ }^{\circledR R}-300$ System, Heidolph Instruments $\mathrm{GmbH} \& \mathrm{CO}$. KG, Germany) before it underwent a final purification process by open column chromatography (Merck silica gel 60, mesh 70-230 and elution with 95\% chloroform:5\% methanol) to produce DHHPD (Figure 7). The structure and the purity of the compound were identified and characterized by using ${ }^{1} \mathrm{H}-\mathrm{NMR}$ and ${ }^{13} \mathrm{C}-\mathrm{NMR}$ (Varian $500 \mathrm{MHz}$, Varian Inc., Palo Alto, California, USA), HPLC utilizing Waters Xbridge C18 column $(5 \mu \mathrm{m}, 150 \mathrm{~mm} \times 4.6 \mathrm{~mm})$ (Thermo Finnigan Surveyor, San Josè, CA, USA) and gas chromatography mass spectrometry (Shimadzu GCMS-QP5050A Mass Spectrometer, Shimadzu, Kyoto, Japan). Colour: Orange; Yield: 37.15\%; m.p.: $155-156{ }^{\circ} \mathrm{C}$; Mass calculated: 298.0841; Mass found: $298.0843 .{ }^{1} \mathrm{H}-\mathrm{NMR}\left(500 \mathrm{MHz}\right.$, acetone- $\left.\mathrm{d}_{6}\right) \delta$ ppm 6.65-6.73 (m, 2H) 6.88-7.00 (m, 3H) $7.11(\mathrm{~d}, J=8.2 \mathrm{~Hz}, 1 \mathrm{H}) 7.23(\mathrm{~s}, 1 \mathrm{H}) 7.52(\mathrm{t}, J=7.86 \mathrm{~Hz}, 1 \mathrm{H})$ $7.61(\mathrm{~d}, J=15.73 \mathrm{~Hz}, 1 \mathrm{H}) 7.92(\mathrm{~d}, J=8.15 \mathrm{~Hz}, 1 \mathrm{H}) 8.28$ (br. s, 1H) 8.61 (br. s, 1H) 12.19 (s, 1H) 14.81 (br. s., $1 \mathrm{H}) .{ }^{13} \mathrm{C}-\mathrm{NMR}(126 \mathrm{MHz}$, acetone) $\delta \mathrm{ppm} 96.4,114.3,115.6,118.3,119.0,119.1,119.1,121.9,127.5$, $128.9,135.8,140.6,145.6,148.0,162.4,176.2,195.6$. A detailed description of the general synthetic steps for DHHPD was given in [28].

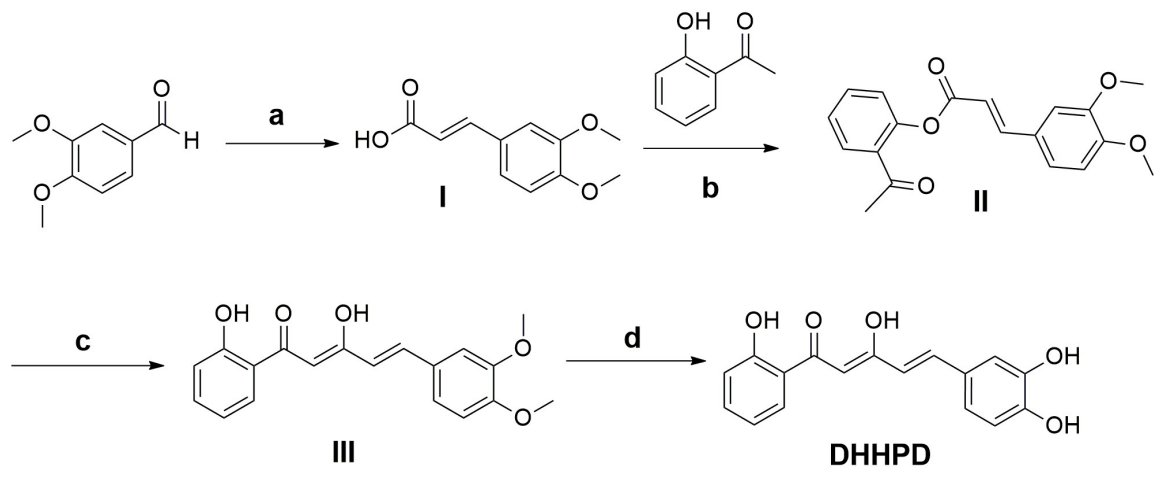

Figure 7. Synthesis of DHHPD. Reagents and Conditions: (a) malonic acid, pyridine, reflux process $(4 \mathrm{~h})$; (b) $\mathrm{POCl}_{3}$, pyridine, $\mathrm{RT}$ (overnight); (c) $\mathrm{KOH}$, pyridine, $\mathrm{RT}$ (overnight); (d) $\mathrm{BBr}_{3}, \mathrm{CH}_{2} \mathrm{Cl}_{2}, 0^{\circ} \mathrm{C}(8 \mathrm{~h}$ ). Reaction scheme and description adapted from [28].

\subsection{Chemicals and Drugs}

The chemicals used are absolute alcohol, dimethyl sulfoxide (DMSO), Tween 20, 0.8\% acetic acid, acetylsalicylic acid, morphine hydrochloride, $2.5 \%$ formalin, naloxone hydrochloride, L-glutamic acid hydrochloride, capsaicin and capsazepine. All chemicals and drugs were bought from Sigma Aldrich (M) Sdn. Bhd., Kuala Lumpur (Malaysia) except for formalin (HMBG Chemicals, Progressive Scientific Sdn. Bhd., Selangor, Malaysia). DHHPD was dissolved in vehicle consisting of 5\% DMSO, 5\% Tween 20 and $90 \%$ distilled water. The final concentration of DMSO and Tween 20 did not surpass 10\% and without apparent negative effect per se. Chemical solutions were freshly prepared prior to the experiment and were administered through intraperitoneal (i.p.) injection at a volume of $10 \mathrm{~mL} / \mathrm{kg}$.

\subsection{Animals}

Male ICR mice (3-4 weeks, 20-30 g) were used throughout the experiments. Prior to the experiments, animals were acclimatized for 7 days in the Animal House, Faculty of Medicine and Health Sciences, UPM. Mice were used only once throughout the study and were immediately euthanized by cervical dislocation at the end of each experiment. Data was gathered in a blinded, randomized and controlled design for all experiments. This project has been approved by the Institutional Animal Care and Use Committee, UPM (Reference: UPM/IACUC/AUP-R088/2017). 


\subsection{Acute Toxicity Test}

Acute toxicity test was performed according to [56], with slight modifications. Mice (6 per group) were fasted overnight and were given DHHPD $(0.1,0.3,1$ and $3 \mathrm{mg} / \mathrm{kg}$, i.p.) and vehicle $(10 \mathrm{~mL} / \mathrm{kg}$, i.p.) on the following day. Observation for occurrence of abnormal behaviours or any incidence of mortality was performed daily for 7 consecutive days. On day 8 , mice from each group were euthanized by cervical dislocation and post mortem was conducted.

\subsection{Antinociceptive Studies}

\subsubsection{Acetic Acid-Induced Writhing Test}

The $0.8 \%$ acetic acid-induced writhing test was conducted according to [57]. Mice (6 per group) were administered with vehicle $(10 \mathrm{~mL} / \mathrm{kg}$, i.p.), acetylsalicylic acid (ASA) $(100 \mathrm{mg} / \mathrm{kg}$, i.p.) and DHHPD $(0.1,0.3,1,3 \mathrm{mg} / \mathrm{kg}$, i.p.) $30 \mathrm{~min}$ prior to the administration of $0.8 \%$ acetic acid at the volume of $10 \mathrm{~mL} / \mathrm{kg}$ (i.p.). The cumulative number of writhes exhibited by each animal was recorded beginning $5 \mathrm{~min}$ after the acetic acid injection for a period of $30 \mathrm{~min}$.

\subsubsection{Formalin-Induced Paw Licking Test}

The $2.5 \%$ formalin-induced paw licking test was conducted based on [58]. Thirty minutes before the intraplantar administration of $20 \mu \mathrm{L}$ of $2.5 \%$ formalin, mice (6 per group) were administered with vehicle $(10 \mathrm{~mL} / \mathrm{kg}$, i.p.), ASA (100 mg $/ \mathrm{kg}$, i.p.), morphine $(5 \mathrm{mg} / \mathrm{kg}$, s.c.) and DHHPD $(0.1,0.3,1$, and $3 \mathrm{mg} / \mathrm{kg}$, i.p.). Each mouse was placed into the Perspex observation chamber immediately and the duration that each mouse spent licking and biting the injected paw at $0-5 \mathrm{~min}$ (early/neurogenic phase) and 15-30 min (late/inflammatory phase) post injection was recorded.

\subsubsection{Hot-Plate Test}

This test was performed according to [40] with slight modifications. Mice were preselected $24 \mathrm{~h}$ before the hot-plate test. Possible variation of results was minimized by selecting only mice with a baseline response latency of six to eight seconds. Mice with a baseline latency of less than $4 \mathrm{~s}$ were considered to be oversensitive and were excluded. Next, mice $(n=6)$ were administered with vehicle (10 mg/ $\mathrm{kg}$, i.p.), morphine ( $5 \mathrm{mg} / \mathrm{kg}$, s.c.) and DHHPD (0.1, 0.3, 1, $3 \mathrm{mg} / \mathrm{kg}$, i.p.), $30 \mathrm{~min}$ prior to the hot-plate test. The hot-plate (Model PE34, Series 8, IITC Inc. Life Science, Victory Blvd Woodland Hills, California, USA) was maintained at $52.5 \pm 0.5{ }^{\circ} \mathrm{C}$ throughout the experiment. Following pre-treatment, mice were immediately placed on the hot-plate once every $30 \mathrm{~min}$ during the $240 \mathrm{~min}$ test period. The response latency recorded was the time taken between the placement of mice on the hot-plate and the display of either shaking, licking of paws or jumping response. The cut-off time set for each mouse on the hot-plate was $20 \mathrm{~s}$ to avoid paw tissue injury.

\subsubsection{Involvement of the Opioidergic System}

A separate group of mice $(n=6)$ received naloxone $(5 \mathrm{mg} / \mathrm{kg}$, i.p), a non-selective opioid receptor antagonist, $15 \mathrm{~min}$ prior to the injection of DHHPD ( $3 \mathrm{mg} / \mathrm{kg}$, i.p.). The subsequent procedure and evaluation for the hot-plate test were repeated.

\subsubsection{Capsaicin-Induced Paw Licking Test}

The capsaicin-induced paw licking test was conducted according to [42]. Mice (6 per group) received vehicle $(10 \mathrm{~mL} / \mathrm{kg}$, i.p.), capsazepine $(0.17 \mathrm{mmol} / \mathrm{kg}$, i.p.) and DHHPD $(0.1,0.3,1,3 \mathrm{mg} / \mathrm{kg}$, i.p.). Thirty minutes post treatment, each mouse was injected with capsaicin $(1.6 \mu \mathrm{g} / \mathrm{paw}, 20 \mu \mathrm{L}$, i.pl.) on its left hind paw. Mice were placed in a cylindrical Perspex observation chamber immediately and were observed for $5 \mathrm{~min}$. The duration that each mouse spent on licking the injected paw was recorded as an indicator of nociception. 


\subsubsection{Glutamate-Induced Paw Licking Test}

This test was conducted according to [59]. Mice $(n=6)$ were administered with vehicle $(10 \mathrm{~mL} / \mathrm{kg}$, i.p.), ASA (100 mg/kg, i.p.) and DHHPD (0.1, 0.3, 1, $3 \mathrm{mg} / \mathrm{kg}$, i.p.). Each mouse was injected with a glutamate solution $(10 \mu \mathrm{mol} / \mathrm{paw}, 20 \mu \mathrm{L}$, i.pl) on its left hind paw, $30 \mathrm{~min}$ after the pre-treatment. Mice were transferred into a cylindrical Perspex observation chamber immediately and were observed for $15 \mathrm{~min}$. The duration that each mouse spent on licking and biting its injected paw was recorded.

\subsection{Motor Performance Test}

\section{Rotarod Test}

The rotarod test was performed according to [60], with slight modification. Mice were pre-selected $24 \mathrm{~h}$ prior to the rotarod test. Mice that were capable of remaining on the revolving bar of the rotarod (Ugo-Basile, model 47600, Gemonio (VA), Italy) at $20 \mathrm{rpm}$ for two consecutive periods of $60 \mathrm{~s}$ without failing were selected. Following pre-selection, mice (6 per group) were administered with vehicle ( $10 \mathrm{~mL} / \mathrm{kg}$, i.p.), DHHPD (0.1, 0.3, 1 and $3 \mathrm{mg} / \mathrm{kg}$, i.p.) and diazepam $(4 \mathrm{mg} / \mathrm{kg}$, i.p.), $30 \mathrm{~min}$ prior to the test. Following pre-treatment, mice were placed on the revolving bar of the rotarod $(20 \mathrm{rpm})$ and their motor performance was assessed at 30,60 and $90 \mathrm{~min}$. The length of time each mouse remained on the revolving bar was recorded.

\subsection{Statistical Analysis}

Statistical differences between groups were analysed using analysis of variance (ANOVA) with $p<0.05$ as the limit of significance with Dunnett's test as the post hoc test. Results from the hot-plate test were analysed by a two-way ANOVA followed by the Bonferonni post hoc test. The $\mathrm{ED}_{50}$ value (effective dose producing 50\% inhibition in accordance to control value) was determined by nonlinear regression analysis using GraphPad Prism 6 (GraphPad Software Inc., San Diego, CA, USA). Results for all experiments are expressed as mean \pm SEM.

\section{Conclusions}

In conclusion, DHHPD ( 1 and $3 \mathrm{mg} / \mathrm{kg}$ ) showed excellent inhibition of nocifensive behaviour as shown in the acetic acid-induced writhing test, formalin-induced paw licking test and the hot-plate test. The peripheral and central antinociception may be mediated by modulation of the vanilloid pathway and glutamatergic system but does not involve the participation of opioidergic system. Further research on the effect of DHHPD in inhibiting the synthesis/release of inflammatory mediators by means of in vivo animal models of inflammation is recommended.

Author Contributions: “Conceptualization, N.K., N.H., H.M.O., A.F.A.A., M.R.S. and W.M.S.M.; Formal analysis, N.K., N.H., H.M.O., A.F.A.A., M.R.S. and W.M.S.M.; Funding acquisition, W.M.S.M.; Investigation, N.H., S.W.L. and W.M.S.M.; Methodology, N.K., N.H., H.M.O., A.F.A.A., M.R.S. and W.M.S.M.; Project administration, N.K., N.H. and W.M.S.M.; Resources, H.M.O., A.F.A.A., S.W.L., F.A., M.R.S. and W.M.S.M.; Supervision, M.R.S. and W.M.S.M.; Validation, S.W.L., F.A. and M.R.S.; Visualization, S.W.L. and F.A.; Writing-original draft, N.K.; Writing-review \& editing, N.K. and W.M.S.M." The manuscript is submitted with the agreement and approval of all authors.

Funding: This research received no external funding.

Acknowledgments: The authors would like to express their gratitude to the Faculty of Veterinary Medicine, Faculty of Medicine and Health Sciences and Institute of Bioscience of Universiti Putra Malaysia for the facilities provided. N.K. and N.H. received the Graduate Research Fellowship from UPM and MyMaster scholarship from the Ministry of Higher Education, Malaysia.

Conflicts of Interest: The authors declare no conflict of interest. 


\section{References}

1. Zhang, Y.; Wang, C.; Wang, L.; Parks, G.S.; Zhang, X.; Guo, Z.; Ke, Y.; Li, K.; Kim, M.K.; Vo, B.; et al. A novel analgesic isolated from a traditional Chinese medicine. Curr. Biol. 2014, 24, 117-123. [CrossRef] [PubMed]

2. Basbaum, A.I.; Bautista, D.M.; Scherrer, G.; Julius, D. Cellular and molecular mechanisms of pain. Cell 2010, 139, 267-284. [CrossRef] [PubMed]

3. Simmons, D.L. What makes a good anti-inflammatory drug target? Drug Discov. Today 2006, 11, $210-219$. [CrossRef]

4. North, R.A. Drug receptors and the inhibition of nerve cells. Br. J. Pharmacol. 1989, 98, 13-28. [CrossRef] [PubMed]

5. Honey; Thareja, S.; Kumar, M.; Sinha, V.R. Self-organizing molecular field analysis of NSAIDs: Assessment of pharmacokinetic and physicochemical properties using 3D-QSPkR approach. Eur. J. Med. Chem. 2012, 53, 76-82. [CrossRef]

6. Bavry, A.A.; Khaliq, A.; Gong, Y.; Handberg, E.M.; Cooper-DeHoff, R.M.; Pepine, C.J. Harmful Effects of NSAIDs among Patients with Hypertension and Coronary Artery Disease. Am. J. Med. 2011, 124, 614-620. [CrossRef] [PubMed]

7. Deghrigue, M.; Festa, C.; Ghribi, L.; D’Auria, M.V.; De Marino, S.; Ben Jannet, H.; Bouraoui, A. Anti-inflammatory and analgesic activities with gastroprotective effect of semi-purified fractions and isolation of pure compounds from Mediterranean gorgonian Eunicella singularis. Asian Pac. J. Trop. Med. 2015, 8, 606-611. [CrossRef] [PubMed]

8. Bertam, G.K. Basic and Clinical Pharmacology, 7th ed.; Appleton \& Lange: New York, NY, USA, 1998; pp. 496-513, ISBN 0838505651.

9. Akil, H.; Owens, C.; Gutstein, H.; Taylor, L.; Curran, E.; Watson, S. Endogenous opioids: Overview and current issues. Drug Alcohol. Depend. 1998, 51, 127-140. [CrossRef]

10. Terman, G.W.; Shavit, Y.; Lewis, J.W.; Cannon, J.T.; Liebeskind, J.C. Intrinsic mechanisms of pain inhibition: Activation by stress. Science 1984, 226, 1270-1277. [CrossRef] [PubMed]

11. Porreca, F.; Ossipov, M.H. Nausea and vomiting side effects with opioid analgesics during treatment of chronic pain: Mechanisms, implications, and management options. Pain Med. 2009, 10, 654-662. [CrossRef] [PubMed]

12. Benyamin, R.; Trescot, A.; Datta, S.; Buenaventura, R.; Adlaka, R.; Sehgal, N.; Glaser, S.E.; Vallejo, R. Opioid complications and side effects. Pain Phys. 2008, 11, S105-S120.

13. McNicol, E.; Horowicz-Mehler, N.; Fisk, R.; Bennett, K.; Gialeli-Goudas, M.; Chew, P.; Lau, J.; Carr, D. Management of opioid side effects in cancer-related and chronic noncancer pain: A systematic review. J. Pain 2003, 4, 231-256. [CrossRef]

14. Neal, M.J. Medical Pharmacology at a Glance, 3rd ed.; Blackwell Science Inc.: Hoboken, NJ, USA, 1997; pp. 64-65.

15. Shipton, E.A. Development of narcotic addiction, tolerance and crosstolerance. S. Afr. Med. J. 1984, 66, 163. [PubMed]

16. Max, M.B.; Payne, R.; Edwards, W.T.; Sunshine, A.; Inturrisi, C.E. Principles of Analgesic Use in the Treatment of Acute Pain and Cancer Pain, 4th ed.; American Pain Society: Glenview, IL, USA, 1999.

17. Portenoy, R.K.; Payne, R. Acute and chronic pain. In Comprehensive Textbook of Substance Abuse, 3rd ed.; Lowinson, J.H., Ruiz, P., Millman, R., Eds.; Williams \& Wilkins: Baltimore, MD, USA, 1997.

18. Chapman, C.R.; Hill, H.F. Prolonged morphine self-administration and addiction liability. Evaluation of two theories in a bone marrow transplant unit. Cancer 1989, 63, 1636-1644. [CrossRef]

19. Newman, R.G. The need to redefine "addiction". N. Engl. J. Med. 1983, 308, 1096-1098. [CrossRef] [PubMed]

20. Yob, N.J.; Jofrry, S.M.; Affandi, M.M.R.M.M.; Teh, L.K.; Salleh, M.Z.; Zakaria, Z.A. Zingiber zerumbet (L.) Smith: A Review of Its Ethnomedicinal, Chemical, and Pharmacological Uses. Evid. Based Complement. Altern. Med. 2011, 2011, 12. [CrossRef] [PubMed]

21. Suloon, J.; Sulaiman, M.R.; Azlina, N.; Abu Bakar, N.A.; Makhtar, N.A.; Ismail, N.I.; Lee, M.T.; Kamaldin, M.N.; Mohamad, A.S.; Lajis, N.; et al. Antinociceptive Activity of Curcuma longa Essential Oil. UMTAS 2011, 2011, 555-560.

22. Ammon, H.P.T.; Anazodo, M.I.; Safayhi, H.; Dhawan, B.N.; Srimal, R.C. Curcumin: A potent inhibitor of leukotriene B4 formation in rat peritoneal polymorphonuclear neutrophils (PMNL). Planta Med. 1992, 58, 226. [CrossRef] [PubMed] 
23. Azuine, M.A.; Bhide, S.V. Chemopreventive effect of turmeric against stomach and skin tumors induced by chemical carcinogens in Swiss mice. Nutr. Cancer 1992, 17, 77-83. [CrossRef] [PubMed]

24. Ammon, H.; Wahl, M. Pharmacology of Curcuma longa. Planta Med. 1991, 57, 1-7. [CrossRef] [PubMed]

25. Kuttan, R.; Bhanumathy, P.; Nirmala, K.; George, M.C. Potential anticancer activity of turmeric (Curcuma longa). Cancer Lett. 1985, 29, 197-202. [CrossRef]

26. Anand, P.; Thomas, S.G.; Kunnumakkara, A.B.; Sundaram, C.; Harikumar, K.B.; Sung, B.; Tharakan, S.T.; Misra, K.; Priyadarsini, I.K.; Rajasekharan, K.N.; et al. Biological activities of curcumin and its analogues (Congeners) made by man and Mother Nature. Biochem. Pharmacol. 2008, 76, 1590-1611. [CrossRef] [PubMed]

27. Liang, G.; Shao, L.; Wang, Y.; Zhao, C.; Chu, Y.; Xiao, J.; Zhao, Y.; Li, X.; Yang, S. Exploration and synthesis of curcumin analogues with improved structural stability both in vitro and in vivo as cytotoxic agents. Bioorg. Med. Chem. 2009, 17, 2623-2631. [CrossRef] [PubMed]

28. Leong, S.W.; Mohd Faudzi, S.M.; Abas, F.; Mohd Aluwi, M.F.F.; Rullah, K.; Wai, L.K.; Abdul Bahari, M.N.; Ahmad, S.; Tham, C.L.; Shaari, K.; et al. Synthesis and sar study of diarylpentanoid analogues as new anti-inflammatory agents. Molecules 2014, 19, 16058-16081. [CrossRef] [PubMed]

29. Lee, K.H.; Farida, F.H.; Syahida, A.; Abas, F.; Shaari, K.; Israf, D.A.; Lajis, N.H. Synthesis and biological evaluation of curcumin-like diarylpentanoid analogues for anti-inflammatory, antioxidant and anti-tyrosinase activities. Eur. J. Med. Chem. 2009, 44, 3195-3200. [CrossRef] [PubMed]

30. Ahmad Wani, T.; Kumar, D.; Prasad, R.; Verma, P.K.; Sardar, K.K.; Tandan, S.K.; Kumar, D. Analgesic activity of the ethanolic extract of Shorea robusta resin in experimental animals. Indian J. Pharmacol. 2012, 44, 493-499. [CrossRef]

31. Couto, V.M.; Vilela, F.C.; Dias, D.F.; Santos, M.H.; Soncini, R.; Nascimento, C.G.O.; Giusti-paiva, A. Antinociceptive effect of extract of Emilia sonchifolia in mice. J. Ethnopharmacol. 2011, 134, 348-353. [CrossRef] [PubMed]

32. Woode, E.; Amoh-Barimah, A.K.; Abotsi, W.K.M.; Ainooson, G.K.; Owusu, G. Analgesic effects of stem bark extracts of Trichilia monadelpha (Thonn.) JJ De Wilde. Indian J. Pharmacol. 2012, 44, 765-773. [CrossRef] [PubMed]

33. De Sousa, D.P. Analgesic-like activity of essential oils constituents. Molecules 2011, 16, 2233-2252. [CrossRef] [PubMed]

34. Farouk, L.; Laroubi, A.; Aboufatima, R.; Benharref, A.; Chait, A. Evaluation of the analgesic effect of alkaloid extract of Peganum harmala L.: Possible mechanisms involved. J. Ethnopharmacol. 2008, 115, 449-454. [CrossRef] [PubMed]

35. Garcia, M.; Fernandez, M.; Alvarez, A.; Saenz, M. Antinociceptive and anti-inflammatory effect of the aqueous extract from leaves of Pimenta racemosa var. ozua (Mirtaceae). J. Ethnopharmacol. 2004, 91, 69-73. [CrossRef] [PubMed]

36. Sulaiman, M.R.; Hussain, M.K.; Zakaria, Z.A.; Somchit, M.N.; Moin, S.; Mohamad, A.S.; Israf, D.A. Evaluation of the antinociceptive activity of Ficus deltoidea aqueous extract. Fitoterapia 2008, 79, 557-561. [CrossRef] [PubMed]

37. Gonzalez-Trujano, M.; Pena, E.; Martinez, A.; Moreno, J.; Guevara-Fefer, P.; Deciga-Campos, M.; Lopez-Moreno, F. Evaluation of the antinociceptive effect of Rosmarinus officinalis L. using three different experimental models in rodents. J. Ethnopharmacol. 2007, 111, 476-482. [CrossRef] [PubMed]

38. Hossain, C.F.; Al-Amin, M.; Rahman, K.M.M.; Sarker, A.; Alam, M.M.; Chowdhury, M.H.; Khan, S.N.; Sultana, G.N.N. Analgesic principle from Curcuma amada. J. Ethnopharmacol. 2015, 163, 273-277. [CrossRef] [PubMed]

39. Moniruzzaman, M.; Imam, M.Z. Evaluation of antinociceptive effect of methanolic extract of leaves of Crataeva nurvala Buch.-Ham. BMC Complement. Altern. Med. 2014, 14, 354. [CrossRef] [PubMed]

40. Ming-Tatt, L.; Khalivulla, S.I.; Akhtar, M.N.; Mohamad, A.S.; Perimal, E.K.; Khalid, M.H.; Akira, A.; Lajis, N.; Ahmad Israf, D.; Sulaiman, M.R. Antinociceptive Activity of a Synthetic Curcuminoid Analogue, 2,6-bis-(4-hydroxy-3-methoxybenzylidene)cyclohexanone, on Nociception-induced Models in Mice. Basic Clin. Pharmacol. Toxicol. 2012, 110, 275-282. [CrossRef] [PubMed]

41. Bastos, G.N.T.; Santos, A.R.S.; Ferreira, V.M.M.; Costa, A.M.R.; Bispo, C.I.; Silveira, A.J.A.; Do Nascimento, J.L.M. Antinociceptive effect of the aqueous extract obtained from roots of Physalis angulata L. on mice. J. Ethnopharmacol. 2006, 103, 241-245. [CrossRef] [PubMed]

42. Ismail, N.I.; Ming-Tatt, L.; Lajis, N.; Akhtar, M.N.; Akira, A.; Perimal, E.K.; Israf, D.A.; Sulaiman, M.R. Antinociceptive Effect of 3-(2,3-Dimethoxyphenyl)-1-(5-methylfuran-2-yl)prop-2-en-1-one in Mice Models of Induced Nociception. Molecules 2016, 21, 1077. [CrossRef] [PubMed] 
43. Hajhashemi, V.; Ghannadi, A.; Pezeshkian, S.K. Antinociceptive and anti-inflammatory effects of Satureja hortensis L. extracts and essential oil. J. Ethnopharmacol. 2002, 82, 83-87. [CrossRef]

44. Viana, A.F.; Heckler, A.P.; Fenner, R.; Rates, S.M.K. Antinociceptive activity of Hypericum caprifoliatum and Hypericum polyanthemum (Guttiferae). Braz. J. Med. Biol. Res. 2003, 36, 631-634. [CrossRef] [PubMed]

45. Hitner, H.; Nagle, B. Basic Pharmacology, 4th ed.; Glencoe/McGraw-Hill Education: New York, NY, USA, 2002; pp. 219-254, ISBN 0028046544.

46. Khatun, A.; Imam, M.; Rana, M. Antinociceptive effect of methanol extract of leaves of Persicaria hydropiper in mice. BMC Complement. Altern. Med. 2015, 15, 63. [CrossRef] [PubMed]

47. Fattori, V.; Hohmann, M.; Rossaneis, A.; Pinho-Ribeiro, F.; Verri, W. Capsaicin: Current Understanding of Its Mechanisms and Therapy of Pain and Other Pre-Clinical and Clinical Uses. Molecules 2016, 21, 844. [CrossRef] [PubMed]

48. Lebovitz, E.E.; Keller, J.M.; Kominsky, H.; Kaszas, K.; Maric, D.; Iadarola, M.J. Positive Allosteric Modulation of TRPV1 as a Novel Analgesic Mechanism. Mol. Pain 2012, 8, 1-14. [CrossRef] [PubMed]

49. Cui, M.; Gosu, V.; Basith, S.; Hong, S.; Choi, S. Polymodal Transient Receptor Potential Vanilloid Type 1 Nocisensor: Structure, Modulators, and Therapeutic Applications. Adv. Protein Chem. Struct. Biol. 2016, 104, 81-125. [PubMed]

50. Chizh, B.A.; O’Donnell, M.B.; Napolitano, A.; Wang, J.; Brooke, A.C.; Aylott, M.C.; Bullman, J.N.; Gray, E.J.; Lai, R.Y.; Williams, P.M.; et al. The effects of the TRPV1 antagonist SB-705498 on TRPV1 receptor-mediated activity and inflammatory hyperalgesia in humans. Pain 2007, 132, 132-141. [CrossRef] [PubMed]

51. Bleakman, D.; Alt, A.; Nisenbaum, E.S. Glutamate receptors and pain. Semin. Cell Dev. Biol. 2006, 17, 592-604. [CrossRef] [PubMed]

52. Nucci-Martins, C.; Martins, D.F.; Nascimento, L.F.; Venzke, D.; Oliveira, A.S.; Frederico, M.J.S.; Silva, F.R.M.B.; Brighente, I.M.C.; Pizzolatti, M.G.; Santos, A.R.S. Ameliorative potential of standardized fruit extract of Pterodon pubescens Benth on neuropathic pain in mice: Evidence for the mechanisms of action. J. Ethnopharmacol. 2015, 175, 273-286. [CrossRef] [PubMed]

53. Osikowicz, M.; Mika, J.; Przewlocka, B. The glutamatergic system as a target for neuropathic pain relief. Exp. Physiol. 2013, 98, 372-384. [CrossRef] [PubMed]

54. Beirith, A.; Santos, A.R.S.; Calixto, J.B. Mechanisms underlying the nociception and paw oedema caused by injection of glutamate into the mouse paw. Brain Res. 2002, 924, 219-228. [CrossRef]

55. Beirith, A.; Santos, A.R.S.; Rodrigues, A.L.S.; Creczynski-Pasa, T.B.; Calixto, J.B. Spinal and supraspinal antinociceptive action of dipyrone in formalin, capsaicin and glutamate tests. Study of the mechanism of action. Eur. J. Pharmacol. 1998, 345, 233-245. [CrossRef]

56. Azmi, F.; Leong, S.W.; Abas, F.; Ming, O.H.; Perimal, E.K.; Akira, A.; Ahmad Israf, D.; Sulaiman, M.R. Antinociceptive effect of 2-benzoyl-6-(3,4-dihydroxybenzylidene)cyclohexen-1-ol on nociception induced models in mice. J. Pharmacol. Toxicol. Investig. 2016, 2, 1-9.

57. Sulaiman, M.R.; Perimal, E.K.; Zakaria, Z.A.; Mokhtar, F.; Akhtar, M.N.; Lajis, N.H.; Israf, D.A. Preliminary analysis of the antinociceptive activity of zerumbone. Fitoterapia 2009, 80, 230-232. [CrossRef] [PubMed]

58. Mohamad, A.S.; Akhtar, M.N.; Zakaria, Z.A.; Perimal, E.K.; Khalid, S.; Mohd, P.A.; Khalid, M.H.; Israf, D.A.; Lajis, N.H.; Sulaiman, M.R. Antinociceptive activity of a synthetic chalcone, flavokawin B on chemical and thermal models of nociception in mice. Eur. J. Pharmacol. 2010, 647, 103-109. [CrossRef] [PubMed]

59. Guilhon, C.C.; Rahayu, I.; Wahab, A.; Boylan, F.; Fernandes, P.D. Central Antinociceptive and Mechanism of Action of Pereskia bleo Kunth Leaves Crude Extract, Fractions, and Isolated Compounds. Evid. Based Complement. Altern. Med. 2015, 2015. [CrossRef] [PubMed]

60. Ong, H.M.; Mohamad, A.S.; Makhtar, N.; Khalid, M.H.; Khalid, S.; Perimal, E.K.; Mastuki, S.N.; Zakaria, Z.A.; Lajis, N.; Ahmad Israf, D.; et al. Antinociceptive activity of methanolic extract of Acmella uliginosa (Sw.) Cass. J. Ethnopharmacol. 2011, 133, 227-233. [CrossRef] [PubMed]

Sample Availability: Samples of the compound, DHHPD 5-(3,4-dihydroxyphenyl)-3-hydroxy-1-(2-hydroxyphenyl) penta-2,4-dien-1-one, are available from F.A., S.W.L. and M.R.S.

(C) 2018 by the authors. Licensee MDPI, Basel, Switzerland. This article is an open access article distributed under the terms and conditions of the Creative Commons Attribution (CC BY) license (http://creativecommons.org/licenses/by/4.0/). 